\title{
PEMBELAJARAN MATEMATIKA BERBASIS-MASALAH YANG MENGHADIRKAN KECERDASAN EMOSIONAL
}

Oleh:

Ibrahim

Dosen Prodi. Pendidikan Matematika Fakultas Sains dan Teknologi UIN Sunan Kalijaga ibrahim311079@live.com

\begin{abstract}
Abstrak
Pembelajaran berbasis-masalah dalam konteks pembelajaran matematika adalah suatu strategi pembelajaran matematika di dalam kelas dengan aktivitas memecahkan masalah matematis sedemikian hingga siswa dapat mengkonstruksi pengetahuan matematis oleh dirinya sendiri. Berkaitan dengan usaha mencapai tujuan pembelajaran matematika melalui pembelajaran berbasis-masalah, tentunya menuntut siswa untuk menggunakan potensinya secara optimal. Sementara itu, untuk menciptakan proses pembelajaran matematika dengan penggunaan potensi siswa secara optimal, maka kecerdasan emosional yang dimiliki siswa perlu menjadi perhatian. Pertimbangan emosional dalam pembelajaran matematika secara istimewa mungkin akan sedikit banyak membantu dalam menerima pelajaran matematika, di tengah anggapan yang masih diyakini oleh sebagian besar siswa, yaitu matematika merupakan mata pelajaran yang sulit. Dengan demikian, kehadiran kecerdasan emosional dapat dipandang sebagai aspek yang perlu dipertimbangkan, bahkan dapat dijadikan dasar untuk mengikuti proses pembelajaran berbasis-masalah dengan baik sedemikian hingga tercapainya hasil pembelajaran matematika secara utuh.
\end{abstract}

Kata kunci : pembelajaran berbasis-masalah dan kecerdasan emosional

\section{A. Pendahuluan}

Pernyataan yang dinyatakan oleh Mettes dalam salah satu tulisannya di tahun 1979, yaitu bahwa dalam belajar matematika siswa hanya mencontoh dan mencatat cara menyelesaikan soal yang telah dikerjakan oleh gurunya, ternyata masih dapat dikatakan relevan dengan cara belajar matematika di kelas-kelas sekolah saat ini. Jika para siswa diberi soal yang berbeda dengan soal latihan, maka mereka kebingungan untuk menyelesaikannya. Hal ini, karena siswa tidak tahu harus memulai dari mana mereka bekerja untuk menyelesaikan soal. Demikian juga pernyataan Crockcroft dalam salah satu tulisannya di tahun 1981, yaitu matematika merupakan pelajaran yang sulit untuk diajarkan dan dipelajari, ternyata masih dapat dikatakan relevan dengan keadaan saat ini. Kesulitan ini terjadi karena matematika diajarkan lebih ditekankan pada anggapan bahwa matematika adalah pelajaran yang bersifat abstrak, deduktif, dan pengetahuan yang sudah jadi. Keadaan ini bertambah buruk dengan tidak sedikit praktik-praktik pembelajaran matematika di dalam kelas yang kurang komunikatif, monoton dan mengabaikan emosional siswa, serta terkesan hanya menggunakan bahasa-bahasa angka dan simbol semata. Dengan demikian, 
sesungguhnya permasalahan-permasalahan yang muncul selama lebih dari dua dekade tidak jauh berbeda.

Fakta-fakta yang diutarakan di atas tentu saja kurang mendukung terhadap upaya pencapaian tujuan matematika diajarakan di sekolah untuk saat ini dan masa yang akan datang. Terlebih, apabila fakta ini dikaitkan dengan pencapaian visi pendidikan matematika yang mempunyai dua arah pengembangan, yaitu memenuhi kebutuhan masa kini dan masa yang akan datang (Sumarmo, 2005). Visi pertama untuk kebutuhan masa kini, yaitu pembelajaran matematika mengarah pada pemahaman konsep-konsep yang diperlukan untuk menyelesaikan masalah matematis dan ilmu pengetahuan lainnya. Visi kedua untuk kebutuhan masa yang akan datang atau mengarah ke masa depan, yaitu pembelajaran matematika mengarah pada kemampuan nalar yang logis, sistematis, kritis, dan cermat serta berpikir objektif dan terbuka yang sangat diperlukan dalam kehidupan sehari-hari serta diperlukan untuk menghadapi masa depan yang selalu berubah.

Fakta-fakta yang ada saat ini memberikan petunjuk untuk segera memperbaiki kelemahan-kelamahan dari proses pembelajaran matematika di kelas. Karena, apabila kelemahan semacam ini tidak diantisipasi dan tidak diperbaiki maka akan selalu terjadi dan akan menghambat pada pencapaian tujuan pembelajaran matematika yang lebih jauh. Untuk itu, diperlukan alternatif pembelajaran matematika yang berkualitas, yaitu pembelajaran matematika yang memberikan peluang lebih banyak pada siswa untuk mengembangkan potensinya sebagai bekal di kehidupan saat ini dan kehidupan yang akan datang.

Salah satu alternatif pembelajaran yang memberikan peluang tercapainya tujuan pembelajaran matematika adalah pembelajaran berbasis-masalah (selanjutnya disingkat PBM). Pembelajaran berbasis-masalah (Problem-Based Learning) adalah suatu pembelajaran yang diawali dengan menghadapkan siswa pada suatu masalah (Savery dan Duffy, 1995, h. 8; Tan, 2004, h. 7; Weissinger, 2004, h. 46). Dalam konteks pembelajaran matematika Shoenfeld dan Boaler (Roh, 2003, h. 1) menyatakan bahwa PBM adalah suatu strategi pembelajaran matematika di dalam kelas dengan aktivitas memecahkan masalah serta memberikan peluang lebih banyak pada siswa untuk berpikir kritis, kreatif, bernalar, dan berkomunikasi matematis dengan teman sebayanya. Dalam PBM siswa dituntut untuk menyelesaikan masalah yang sengaja diberikan oleh guru dengan berbekal pengetahuan, kemampuan, dan pengalaman yang dimiliki siswa.

Sebagaimana dinyatakan di bagian depan bahwa matematika adalah suatu mata pelajaran yang ada di sekolah, serta sampai saat ini tidak jarang dianggap sebagai mata pelajaran yang sulit bagi pada umumnya siswa. Kesulitan siswa 
dalam mempelajari matematika mungkin saja membuat siswa menjadi tidak senang terhadap matematika, sebagaimana yang dinyatakan Ruseffendi (1988, h. 15) bahwa matematika bagi siswa pada umumnya merupakan mata pelajaran yang dibenci atau tidak disenangi. Kebencian atau ketidaksenangan ini akan berpengaruh terhadap keberhasilan siswa dalam belajar matematika. Sejalan dengan hal ini, hasil penelitian Martin tahun 2003 pada siswa-siswa SLTP di Indonesia yang ber-IQ tinggi, yaitu di atas 120, mengungkapkan bahwa sebagian besar kegagalan siswa dalam mata pelajaran matematika di sekolah bukan disebabkan pada IQ mereka tetapi pada pengendalian emosionalnya (Martin, 2003).

Berkaitan dengan usaha mencapai tujuan-tujuan pembelajaran matematika melalui pembelajaran berbasis-masalah, tentunya menuntut siswa untuk menggunakan potensinya secara optimal. Sementara itu, untuk menciptakan proses pembelajaran dengan penggunaan potensi siswa secara optimal, Shapiro (2003) menyatakan bahwa kecerdasan emosional yang dimiliki siswa perlu menjadi perhatian. Pertimbangan emosional dalam pembelajaran matematika secara istimewa mungkin akan sedikit banyak membantu dalam menerima pelajaran matematika. Dengan demikian, kehadiran kecerdasan emosional dapat dipandang sebagai aspek yang perlu dipertimbangkan, bahkan dapat dijadikan dasar untuk mengikuti proses pembelajaran berbasis-masalah dengan baik.

Berdasarkan uraian di atas, maka keperluan untuk melakukan studi atau kajian yang berfokus pada pembelajaran berbasis-masalah yang menghadirkan kecerdasan emosional, dipandang sangat urgen dan utama untuk dilakukan. Dalam hubungan ini, maka penulis mencoba untuk mengkaji yang berkaitan dengan PBM dan kecerdasan emosional.

\section{B. Pembelajaran Berbasis-Masalah}

Selama hampir dua dekade sejak penerbitan dokumen asli Standar NCTM (National Council of Teacher of Mathematics) pada tahun 1989, bukti-bukti yang menyatakan bahwa pemecahan masalah merupakan sarana yang diduga kuat dan efektif untuk belajar, terus menumpuk. NCTM (2000) mengemukakan bahwa pemecahan masalah merupakan bagian yang tak terpisahkan dari semua proses belajar matematika, sehingga seharusnya tidak dijadikan sebagai bagian yang terpisah dari program pengajaran matematika. Jadi, para siswa memecahkan masalah bukan untuk menerapkan matematika, tetapi untuk belajar matematika yang baru.

Saat siswa melibatkan diri dalam tugas-tugas berbasis-masalah yang dipilih dengan baik dan memfokuskan pada metode-metode penyelesaiannya, maka 
yang menjadi hasilnya adalah pemahaman baru tentang matematika yang disisipkan di dalam masalah tersebut. Ketika siswa sedang aktif mencari hubungan, menganalisis pola, menemukan metode yang sesuai atau tidak sesuai, menguji hasil, atau menilai dan mengkritisi pemikiran temannya, maka mereka secara optimal sedang melibatkan diri dalam berpikir reflektif tentang ide-ide yang terkait.

Pembelajaran berbasis-masalah (Problem-Based Learning) adalah suatu pembelajaran yang di awali dengan menghadapkan siswa pada suatu masalah (Savery dan Duffy, 1995, h. 8; Tan, 2004, h. 7; Weissinger, 2004, h. 46). PBM lebih menekankan pada pemecahan masalah autentik seperti masalah yang tejadi dalam kehidupan sehari-hari (Tan, 2004). Dalam konteks pembelajaran matematika Shoenfeld dan Boaler (Roh, 2003, h. 1) menyatakan bahwa PBM adalah suatu strategi pembelajaran matematika di dalam kelas dengan aktivitas memecahkan masalah serta memberikan peluang lebih banyak pada siswa untuk berpikir kritis, kreatif, dan berkomunikasi matematis dengan teman sebayanya. Dengan bekal pengetahuan, kemampuan, dan pengalaman yang dimilikinya, dalam PBM siswa dituntut untuk menyelesaikan masalah yang sengaja diberikan oleh guru.

Melalui PBM ini siswa diharapkan akan berfokus pada kegiatan memecahkan masalah. Dalam kegiatan memecahkan masalah tersebut siswa memiliki kesempatan yang luas untuk dapat bertukar ide atau pendapat dengan siswa lainnya sehingga memperoleh pemahaman baru tentang matematika yang disisipkan dalam masalah tersebut. Kemudian dalam kegiatan memecahkan masalah tersebut siswa memiliki kesempatan yang luas untuk dapat mencari hubungan, menganalisis pola, menemukan metode mana yang sesuai atau tidak sesuai, menguji hasil, menilai dan mengkritisi pemikiran temannya dan menciptakan pemikiran berbeda sehingga secara optimal mereka melibatkan diri dalam proses pembelajaran matematika.

Dengan demikian, jelas bahwa melalui PBM siswa dikondisikan atau memiliki peluang besar beraktivitas untuk: (1) membangun pengetahuan matematis baru; (2) mencari, menemukan, dan mengaplikasikan dalam kaitannya dengan materi lain di dalam matematika maupun dalam bidang lain; (3) mencari dan menemukan berbagai cara alternatif untuk mendapatkan solusi serta menentukan cara yang paling efektif untuk menyelesaikan masalah; (4) mengamati, mengkritisi, dan mengembangkan proses penyelesaian masalah; (5) mengkomunikasikan gagasan dengan simbol, tabel, diagram, atau media lain untuk memperjelas keadaan atau masalah; (6) menunjukkan kemampuan dalam membuat, menafsirkan, dan menyelesaikan model matematika dalam pemecahan masalah; dan (7) menggunakan penalaran pada pola dan sifat, melakukan manipulasi matematika dalam membuat generalisasi, menyusun 
bukti, atau menjelaskan gagasan dan pernyataan matematika. Apabila siswa melakukan aktivitas-aktivitas tersebut maka diduga mereka akan memiliki nilai-nilai yang dapat dikembangkan melalui pembelajaran matematika, antara lain: berpikir logis, kritis, dan kreatif, teliti, tekun, kerja keras, rasa ingin tahu, pantang menyerah, menghargai proses, terbuka, dan disiplin.

\section{Masalah Matematis dalam Pembelajaran Berbasis-Masalah}

Dalam melaksanakan PBM, guru harus dapat mengelola kelas serta mengembangkan berbagai permasalahan-permasalahan yang mengarah pada suatu konsep matematika yang akan disampaikan. Permasalahan itu bisa datang dari siswa secara individual atau klasikal, namun demikian belum tentu siswa dapat mengajukan masalah yang baik apalagi yang sesuai dengan topik yang akan dibahas. Jadi, di sini guru harus menyiapkan sejumlah permasalahan yang tepat. Menurut Ibrahim (20011, h. 331) masalah yang digunakan dalam PBM sebaiknya: (1) disesuaikan dengan kondisi siswa, artinya masalah harus didasarkan pada pemahaman terakhir yang dimiliki siswa; (2) dikaitkan dengan matematika yang akan dipelajari siswa, artinya dalam memecahkan masalah atau melaksanakan kegiatan, siswa harus diarahkan untuk memahami matematika yang terkait; (3) memiliki jawaban/penyelesain yang memerlukan penjelasan, artinya penyelasain itu menuntut siswa memberikan alasan secukupnya untuk pembenaran atas jawabannya; (4) menggairahkan dan menantang, artinya masalah dapat diselesaikan dengan bantuan guru di awal penyelesaian dan berangsur-angsur dihentikan bantuannya; (5) tidak terlalu sulit, artinya hindari pemberian masalah yang tidak dapat diselesaikan siswa sekalipun diberikan bantuan yang memadai; dan (6) tidak membosankan, artinya hindari pemberian masalah yang dapat diselesaikan tanpa bantuan sama sekali.

Ciri-ciri masalah yang digunakan dalam PBM menurut Ibrahim yang disebutkan di atas menunjukkan bahwa masalah tersebut dikembangkan agar siswa dapat terlibat berpikir serta mengembangkan matematika yang perlu mereka pelajari dan kuasai.

\section{Fase-fase dalam Pembelajaran Berbasis-Masalah}

Guru-guru di sekolah pada umumnya menggunakan sebagian kecil waktunya untuk menjelaskan atau meninjau ulang ide-ide dan kemudian melanjutkan ke tahap bekerja dan terjebak ditahapan ini, yaitu para siswa mengerjakan latihan soal. Pembelajaran yang diatur dengan pola ini membuat siswa memfokuskan diri pada cara-cara untuk menyelesaikan latihan soal. Guru berkeliling menemui setiap anak untuk menjelaskan kembali yang diperlukan. Hal ini 
sangat berbeda dengan pembelajaran yang didasarkan pada sebuah masalah yang merupakan ciri dari PBM yang terpusat pada siswa.

Menurut Tsuruda (Walle, 2005) bahwa ada tiga fase dalam PBM, yaitu sebagai berikut.

1. Fase sebelum pembelajaran. Ada tiga agenda yang terkait dengan fase sebelum pembelajaran, yaitu: 1) memastikan bahwa para siswa memahami masalah sehingga guru tidak perlu menjelaskan lagi ke setiap siswa; 2) menjelaskan hal-hal yang diharapkan dari siswa sebelum mereka menyelesaikan masalah; dan 3) menyiapkan mental para siswa untuk menyelesaikan masalah dan pikirkan pengetahuan yang telah siswa miliki yang akan berguna untuk membantu memecahakan masalah.

2. Fase selama pembelajaran. Meskipun pada fase ini siswa bekerja sendiri atau dengan pasangannya, terdapat agenda yang jelas yang dapat guru lakukan, yaitu: 1) memberikan siswa kesempatan untuk bekerja tanpa petunjuk dari guru atau hindari bantuan di awal kerja siswa; 2) menggunakan waktu ini untuk mendeteksi perbedaan-perbedaan siswa berpikir, ide-ide apa yang mereka gunakan untuk memecahkan masalah; 3) memberikan bantuan pada saat-saat tertentu yang sesuai, tetapi hanya didasarkan pada ide siswa dan cara siswa berpikir, namun dengan tidak memberitahukan metode pemecahannya; dan 4) memberikan kegiatan yang bermanfaat bagi siswa yang dapat memecahkan masalah lebih awal.

3. Fase sesudah pembelajaran. Dalam fase sesudah pembelajaran, siswa-siswa akan bekerja sebagai komunitas belajar, berdiskusi, menguji, dan menghadapi berbagai macam penyelesaian yang diperoleh siswa. Di sinilah kebanyakan siswa mengungkapkan dan memikirkan secara individual dan secara bersama-sama ide-ide yang dengannya mereka telah bekerja. Kesalahan yang mudah terjadi adalah gagalnya merencanakan waktu yang cukup untuk diskusi atau menggunakan fase selama pembelajaran yang terlalu panjang. Agenda untuk fase setelah pembelajaran dapat dengan mudah untuk dikatakan tetapi sulit untuk dicapai. Agenda tersebut, yaitu: 1) melibatkan siswa dalam diskusi yang produktif dengan mengusahakan mereka bekerja sama sebagai sebuah komunitas belajar; 2) menggunakan kesempatan ini untuk mengetahui cara siswa berpikir dan cara mereka mendekati permasalahan; dan 3) membuat ringkasan ide-ide pokok dan mengidentifikasi masalah-masalah untuk kegiatan selanjutnya.

\section{E. Kecerdasan Emosional}

Secara umum bahwa proses pembelajaran di sekolah adalah proses yang sifatnya kompleks dan menyeluruh. Tidak sedikit orang yang berpendapat, untuk memperkirakan berhasil atau gagal dalam belajar di sekolah menengah atau di perguruan tinggi bagi seseorang, menggunakan Intelligence Quotient 
(IQ) sebagai peramalnya. Alasannya, karena inteligensi merupakan bekal potensial yang akan memudahkan dalam belajar dan pada gilirannya akan menghasilkan prestasi belajar yang optimal.

Kenyataannya, dalam proses pembelajaran di sekolah sering ditemukan siswa yang tidak dapat meraih prestasi belajar yang setara dengan kemampuan inteligensinya. Ada siswa yang mempunyai kemampuan inteligensi tinggi tetapi memperoleh prestasi belajar yang relatif rendah, namun ada siswa yang walaupun kemampuan inteligensinya relatif rendah, dapat meraih prestasi belajar yang relatif tinggi. Itu sebabnya taraf inteligensi bukan merupakan satusatunya faktor yang menentukan keberhasilan seseorang, karena ada faktor lain yang mempengaruhi. Menurut Goleman (2005, h. 44), kecerdasan intelektual (IQ) hanya menyumbang 20\% bagi kesuksesan, sedangkan $80 \%$ adalah sumbangan faktor kekuatan-kekuatan lain, di antaranya adalah kecerdasan emosional atau Emotional Intellegence (EI).

Secara umum kecerdasan emosinal mempunyai peran besar dalam proses pembelajaran bagi siswa (Shapiro, 2003, h. 5). Demikian juga dalam pencapaian kuantitas dan kualitas perolehan pembelajaran siswa yang menggunakan PBM, kecerdasan emosional memiliki peran yang tidak sedikit, terlebih dalam rangka meningkatkan kemampuan pemecahan masalah matematis siswa. Hakikatnya, kecerdasan emosional menjadi pendukung kecerdasan intelektual dalam mencapai keberhasilan belajar.

Kesadaran pentingnya kecerdasan emosional dalam pembelajaran bermula sejak awal abad ke-20. Carl Rogers, 1951; Abraham Maslow, Eysenck, dan Jung, 1923; Perkin, 1974; McGaugh, 1998; MacLean, 1990; dan Goleman, 1996 (Suharnan, 2005) adalah pakar-pakar dalam bidang psikologi pendidikan yang banyak menyumbang dalam perkembangan kecerdasan emosional. Mereka menuliskan peran penting dari emosi dalam pembelajaran dengan menggunakan istilah dan pendekatan yang berlainan. Penelitian demi penelitian pun telah dilakukan sehingga beberapa peneliti semakin meyakini tentang peranannya dalam pembelajaran. Dengan demikian, kecerdasan emosional dalam pembelajaran bukan perkara yang baru dalam konteks pembelajaran serta diyakini berdampak besar pada hasil pembelajaran (Yusof, 2004, h. 218).

Sementara itu, istilah kecerdasan emosional (emotional intelligence) pertama kali dipublikasikan pada tahun 1990 oleh psikolog Peter Salovey dari Yale University dan John D. Mayer dari University of New Hampshire untuk menerangkan kualitas-kualitas emosional yang tampaknya penting bagi keberhasilan (Santrock, 2007, h. 146). Kemudian, emotional intelligence (selanjutnya disingkat EI) ini dipopulerkan oleh Daniel Goleman melalui bukunya yang best seller berjudul Emotional Intelligence. 
Sebenarnya, kecerdasan emosional ini bukan konsep baru dalam dunia psikologi. Lama sebelum Salovey, Mayer, dan Goleman, ada sejumlah nama seperti: (1) E. L. Thorndike di tahun 1920 yang mengungkap tentang social intelligence; (2) L. L. Thurston di tahun 1928 menelaah tentang multiple intelligences khususnya mengenai the nature of intelligence; (3) Robert Leeper di tahun 1948 yang menelaah tentang emosi sebagai sumber informasi; (4) Reuven Bar-On di tahun 1983 menulis disertasinya mengenai emotional intelligence; dan (5) Howard Gardner di tahun 1984 mempublikasikan hasil studinya tentang multiple intelligences.

Uniknya, kecerdasan emosional sangat dipengaruhi oleh lingkungan, tidak bersifat menetap, dapat berubah-ubah setiap saat. Untuk itu peranan lingkungan terutama orang tua pada masa kanak-kanak dan remaja sangat mempengaruhi dalam pembentukan kecerdasan emosional (Goleman, 1996).

Kecerdasan emosional bukanlah lawan kecerdasan intelektual atau kemampuan kognitif, namun keduanya berinteraksi secara dinamis, baik pada tingkatan konseptual maupun praktis. Selain itu, kecerdasan emosional tidak begitu dipengaruhi oleh faktor keturunan (Shapiro, 2003, h. 10).

Sebuah model pelopor lain tentang kecerdasan emosional diajukan oleh Bar-On pada tahun 1992 seorang ahli psikologi Israel, yang mendefinisikan kecerdasan emosional sebagai serangkaian kemampuan pribadi, emosi, dan sosial yang mempengaruhi kemampuan seseorang untuk berhasil dalam mengatasi tuntutan dan tekanan lingkungan (Goleman, 1996, h. 180). Sementara itu, Salovey dan Mayer di tahun 1990 (Salovey, 2005, h. 3) menyatakan :

Maybe the idea of emotional intelligence is not a paradox, but rather, a sensible idea. In an early paper we published, we defined it as the ability to monitor your own and other people's feelings, to discriminate among them that is to tell the difference among them, and to use this information to guide thinking, and guide behavior.

Gardner (Goleman, 1996, h. 50 - 53, Santrock, 2007, h. 146) mengatakan bahwa bukan hanya satu jenis kecerdasan yang monolitik yang penting untuk meraih sukses dalam kehidupan, melainkan ada spektrum kecerdasan yang lebar dengan tujuh varietas utama yaitu linguistik, matematika/logika, spasial, kinestetik, musik, interpersonal dan intrapersonal. Dua varietas utama dari kecerdasan ini oleh Gardner dinamakan kecerdasan pribadi, yang oleh Goleman disebut sebagai kecerdasan emosional.

Selanjutnya, Gardner (Goleman, 1996, h. 50-53; Santrock, 2007, 146-147) menyebutkan bahwa kecerdasan pribadi terdiri dari: (1) kecerdasan antar pribadi (interpersonal) yaitu kemampuan untuk memahami orang lain, hal yang memotivasi mereka, cara mereka bekerja, cara bekerja bahu membahu dengan kecerdasan, dan (2) kecerdasan intra pribadi (intrapersonal) adalah 
kemampuan yang korelatif, tetapi terarah ke dalam diri, kemampuan membentuk suatu model diri sendiri yang teliti dan mengacu pada diri serta kemampuan untuk menggunakan modal tadi sebagai alat untuk menempuh kehidupan secara efektif.

Dalam rumusan lain, Gardner menyatakan bahwa inti kecerdasan antar pribadi itu mencakup "kemampuan untuk membedakan dan menanggapi dengan tepat suasana hati, temperamen, motivasi dan hasrat orang lain." Dalam kecerdasan antar pribadi yang merupakan kunci menuju pengetahuan diri, ia mencantumkan "akses menuju perasaan-perasaan diri seseorang dan kemampuan untuk membedakan perasaan-perasaan tersebut serta memanfaatkannya untuk menuntun tingkah laku”. (Goleman, 1996, h. 53).

Berdasarkan kecerdasan yang dinyatakan oleh Gardner tersebut, Salovey (Goleman, 1996, h.57) memilih kecerdasan interpersonal dan kecerdasan intrapersonal untuk dijadikan sebagai dasar untuk mengungkap kecerdasan emosional pada diri individu. Menurutnya kecerdasan emosional adalah kemampuan seseorang untuk mengenali emosi diri, mengelola emosi, memotivasi diri sendiri, mengenali emosi orang lain (empati) dan kemampuan untuk membina hubungan (kerjasama) dengan orang lain.

Menurut Goleman (1996, h. 512), kecerdasan emosional adalah kemampuan seseorang mengatur kehidupan emosinya dengan inteligensi (to manage our emotional life with intelligence); menjaga keselarasan emosi dan pengungkapannya (the appropriateness of emotion and its expression) melalui keterampilan kesadaran diri, pengendalian diri, motivasi diri, empati dan keterampilan sosial.

Dalam studi literatur ini yang dimaksud dengan kecerdasan emosional adalah kemampuan siswa untuk mengenali emosi diri, mengelola emosi diri, memotivasi diri sendiri, mengenali emosi orang lain (empati) dan kemampuan untuk membina hubungan (kerjasama) dengan orang lain.

Goleman mengutip Salovey (1996, h. 58 - 59) menempatkan kecerdasan pribadi Gardner dalam definisi dasar tentang kecerdasan emosional yang dicetuskannya dan memperluas kemampuan tersebut menjadi lima kemampuan utama, yaitu:

\section{a. Mengenali Emosi Diri}

Mengenali emosi diri sendiri merupakan suatu kemampuan untuk mengenali perasaan sewaktu perasaan itu terjadi. Kemampuan ini merupakan dasar dari kecerdasan emosional, para ahli psikologi menyebutkan kesadaran diri sebagai metamood, yakni kesadaran seseorang akan emosinya sendiri. Menurut Mayer (Goleman, 2000, h. 64) kesadaran diri adalah waspada terhadap suasana hati maupun pikiran tentang suasana hati, bila kurang waspada maka individu 
menjadi mudah larut dalam aliran emosi dan dikuasai oleh emosi. Kesadaran diri memang belum menjamin penguasaan emosi, namun merupakan salah satu prasyarat penting untuk mengendalikan emosi sehingga individu mudah menguasai emosi.

\section{b. Mengelola Emosi}

Mengelola emosi merupakan kemampuan individu dalam menangani perasaan agar dapat terungkap dengan tepat atau selaras, sehingga tercapai keseimbangan dalam diri individu. Menjaga agar emosi yang merisaukan tetap terkendali merupakan kunci menuju kesejahteraan emosi. Emosi berlebihan, yang meningkat dengan intensitas terlampau lama akan mengoyak kestabilan diri (Goleman, 1996, h. 77 - 78). Kemampuan ini mencakup kemampuan untuk menghibur diri sendiri, melepaskan kecemasan, kemurungan atau ketersinggungan dan akibat-akibat yang ditimbulkannya, serta kemampuan untuk bangkit dari perasaan-perasaan yang menekan.

\section{c. Memotivasi Diri Sendiri}

Prestasi harus dilalui dengan dimilikinya motivasi dalam diri individu, yang berarti memiliki ketekunan untuk menahan diri terhadap kepuasan dan mengendalikan dorongan hati, serta mempunyai perasaan motivasi yang positif, yaitu antusianisme, gairah, optimis dan keyakinan diri.

\section{d. Mengenali Emosi Orang Lain}

Kemampuan untuk mengenali emosi orang lain disebut juga empati. Menurut Goleman (1996, h. 57) kemampuan seseorang untuk mengenali orang lain atau peduli, menunjukkan kemampuan empati seseorang. Individu yang memiliki kemampuan empati lebih mampu menangkap sinyal-sinyal sosial yang tersembunyi yang mengisyaratkan apa-apa yang dibutuhkan orang lain sehingga ia lebih mampu menerima sudut pandang orang lain, peka terhadap perasaan orang lain dan lebih mampu untuk mendengarkan orang lain.

Rosenthal dalam penelitiannya menunjukkan bahwa orang-orang yang mampu membaca perasaan dan isyarat non-verbal lebih mampu menyesuaikan diri secara emosional, lebih populer, lebih mudah beragul, dan lebih peka (Goleman, 1996, h. 136). Nowicki, ahli psikologi menjelaskan bahwa anak-anak yang tidak mampu membaca atau mengungkapkan emosi dengan baik akan terus menerus merasa frustasi (Goleman, 1996, h. 172). Seseorang yang mampu membaca emosi orang lain juga memiliki kesadaran diri yang tinggi. Semakin mampu terbuka pada emosinya sendiri, mampu mengenal dan mengakui emosinya sendiri, maka orang tersebut mempunyai kemampuan membaca perasaan orang lain.

\section{e. Membina Hubungan}


Kemampuan dalam membina hubungan merupakan suatu keterampilan yang menunjang popularitas, kepemimpinan dan keberhasilan antar pribadi (Goleman, 1996, h. 59). Keterampilan dalam berkomunikasi merupakan kemampuan dasar dalam keberhasilan membina hubungan. Individu yang kurang bisa membina hubungan dengan orang lain, sulit untuk mendapatkan yang diinginkannya dan sulit juga memahami keinginan serta kemauan orang lain.

Orang-orang yang hebat dalam keterampilan membina hubungan ini akan sukses dalam bidang apapun. Orang berhasil dalam pergaulan karena mampu berkomunikasi dengan lancar pada orang lain. Orang-orang ini populer dalam lingkungannya dan menjadi teman yang menyenangkan karena kemampuannya berkomunikasi (Goleman, 2000, h. 59). Ramah tamah, baik hati, hormat, dan disukai orang lain dapat dijadikan petunjuk positif untuk mengidentifikasi siswa yang mampu membina hubungan dengan orang lain. Sejauhmana kepribadian siswa berkembang dilihat dari banyaknya hubungan interpersonal yang dilakukannya.

\section{F. Kehadiran Kecerdasan Emosional dalam Pembelajaran Matematika Berbasis- Masalah}

Pembelajaran yang holistik, yaitu pembelajaran yang tidak hanya memperhatikan aspek kognitif, namun juga memperhatikan aspek lainnya seperti kecerdasan emosional. Berkaitan dengan hal ini, dalam usaha pencapaian harapan-harapan mengenai hasil pembelajaran matematika dengan menggunakan PBM pun, aspek kecerdasan emosional perlu diperhatikan. Hal ini, karena aspek kecerdasan emosional dipandang sebagai aspek yang dapat dijadikan dasar untuk mengikuti proses pembelajaran berbasis-masalah berjalan secara baik.

Pada PBM siswa diberikan peluang lebih banyak untuk berpikir kritis, kreatif, dan berkomunikasi matematis dengan teman sebayanya. Dengan bekal pengetahuan, kemampuan, dan pengalaman yang dimilikinya, siswa di dalam PBM dituntut untuk menyelesaikan masalah yang sengaja diberikan oleh guru.

Namun demikian, kegiatan memecahkan masalah tersebut tidak mudah begitu saja berjalan secara lancar, jika guru maupun siswa tidak memperhatikan dan mempertimbangkan aspek kecerdasan emosional. Guru yang mengesampingkan aspek kecerdasan emosional, seperti: mudah melontarkan kalimat yang menyinggung siswa; terlalu menekan siswa; menunjukkan sikap yang kesal; dan tidak peduli terhadap kesulitan siswa; akan menghambat siswa menjadi pemecah masalah yang handal (Shapiro, 2003, h. 143). Menurut Shapiro (2003, h. 148 - 149) perilaku guru yang mengesampingkan aspek kecerdasan emosional itu dapat membuat suasana yang tidak mendukung 
kegiatan memecahkan masalah dan tidak membantu perkembangan kecerdasan emosional siswa. Dengan demikian kecerdasan emosional perlu diperhatikan, baik pada diri guru maupun siswa.

Setiap guru yang menggunakan PBM sepantasnya menyadari bahwa pada setiap fase pembelajaran perlu memperhatikan aspek kecerdasan emosional dalam setiap kegiatannya. Pada saat memberikan masalah matematis di fase pertama pembelajaran, guru harus selalu yakin bahwa setiap siswa memahami masalah sebelum menyelesaikannya. Yang harus disadari oleh guru bahwa pandangan siswa terhadap masalah mungkin berbeda dengan pandangan guru. Menyelami emosi siswa dalam memahami masalah yang diberikan merupakan hal perlu dilakukan guru, sehingga dapat mengarahkan atau menyadarkan siswa untuk mengenali emosinya dalam mengahadapi masalah tersebut. Kemampuan siswa untuk mengenali emosinya merupakan hal yang penting, karena dengan itu siswa dapat mengendalikan emosinya secara baik sehingga dapat mengikuti proses pembelajaran dengan baik (Sunandar, 2008, h. 718; Shapiro, 2003, h. 167). Dalam kaiatan ini, siswa akan dapat berkonsentrasi dalam berpikir dengan lebih baik untuk memahami masalah yang diberikan, sehingga dapat menyatakan kembali masalah dengan bahasanya sendiri tanpa merasa terpaksa (Goleman, 1996, h. 271).

Selanjutnya, guru yang menggunakan PBM sepantasnya memandu para siswa untuk dapat merencanakan kegiatan yang harus mereka lakukan, serta mempersiapkan untuk diskusi pada fase pembelajaran ketiga. Guru memandu siswa untuk menuliskan penjelasan secukupnya dari jawaban yang mereka ajukan sehingga mereka siap untuk berdiskusi pada saatnya nanti. Namun, tidak menuntup kemungkinan ketika siswa sudah memahami masalah yang diberikan, kemudian mereka tidak segera merencanakan dan mempersiapkan untuk kegiatan selanjutnya.

Memotivasi siswa untuk memunculkan motivasi dalam dirinya menjadi bagian yang penting pada saat siswa bekerja. Karena, motivasi diri yang dimiliki oleh para siswa mempunyai hubungan yang cukup tinggi dengan stabilitas emosi yang dimiliki oleh siswa tersebut (Sunandar, 2008, h. 718, Martin, 2005, h. 55; ). Dalam kaitan ini, memberikan arahan sebagai kegiatan memotivasi siswa, yaitu arahan agar siswa dapat memandang penjelasan yang cukup merupakan hal yang penting serta bagian yang tak dapat dipisahkan dari setiap penyelesaian. Dengan demikian siswa dapat membuat rencana kegiatan selanjutnya serta persiapan untuk diskusi pada fase pembelajaran ketiga secara optimal.

PBM merupakan suatu pembelajaran yang diawali dengan menghadapkan siswa pada suatu masalah. Dalam hal ini, sangat mungkin ada siswa yang tidak siap menghadapi masalah yang diberikan guru, sehingga tidak heran apabila kemudian siswa tersebut menjadi cemas, bersikap terlalu tegang untuk 
konsentrasi, tidak tenang, dan sebagainya (Goleman, 1996, h. 329 - 330). Pengelolaan emosi menjadi bagian yang penting pada bagian ini, karena dengan emosi yang terkelola secara baik, siswa tidak akan mengalami banyak kesulitan dalam berinteraksi dengan masalah yang dihadapinya (Sunandar, 2008, h. 718; Willis, 2010, h. 83). Dalam kaiatan ini, guru memberikan stimulus untuk memanggil kembali pengetahuan awal siswa terkait dengan masalah yang dihadapinya, sehingga meraka merasa punya bekal untuk meyelesaikan masalah tersebut dan secara simultan emosi siswa pun terkelola dengan baik. Jadi, dalam hal ini guru bertindaklah seperti sistem pendukung, yaitu menyediakan bantuan seperlunya sedemikian hingga emosi siswa selalu stabil (Shapiro, 2003, h. 172).

Pada fase kedua ini, apabila para siswa sudah siap untuk melakukan kegiatan memecahkan masalah maka tetaplah memotivasi mereka untuk memulai kegiatannya. Sebaiknya guru dalam hal ini dapat mengkondisikan agar siswa bekerja dengan pengetahuan awal dan keyakinan mereka sendiri. Dengan kata lain, hindari campur tangan guru yang terlalu banyak. Penilaian guru yang terlalu rendah terhadap kemampuan siswa dalam memecahkan masalah dapat mengakibatkan mereka menjadi kurang percaya diri dalam memecahkan masalah (Shapiro, 2003). Guru harus dapat menahan diri untuk memberikan bantuan, sehingga mereka tetap berjuang menyelesaikan masalah yang diberikan.

Ungkapan guru berkenaan dengan membolehkannya siswa untuk melakukan kesalahan, sangat penting. Karena hal ini akan membuat mereka terlepas dari cemas yang berlebihan (Shapiro, 2003, h. 166 - 169). Sementara itu, di sisi lain Boaler \& Humphies (Walle, 2007, h. 46) menyatakan bahwa kesalahan yang dibuat oleh siswa akan menguntungkan dan memperkaya dalam diskusi. Dengan kata lain, guru harus menerima siswa secara positif ketika ada siswa yang merespon masalah yang diberikan guru jauh dari yang seharusnya. Dan sebaiknya berawal dari respon siswa itulah, guru bisa mengarahkannya pada pengetahuan yang diharapkan dapat dibentuk siswa.

Dalam fase kedua pada PBM, guru dituntut juga memiliki kecerdasan emosional yang memadai. Biasanya guru berkeliling memantau siswa yang sedang bekerja, kemudian sesekali guru menghampiri siswa. Di sini satu kesempatan guru untuk mendengarkan mereka dengan memahami pemikiran, perasaan, dan perilaku siswa, dapat menempatkan diri dalam situasi siswa, serta melihat sesuatu dari sudut pandang mereka (empathy). Selain itu, guru berusaha menciptakan keterbukaan (openness) dan kehangatan (warmness). Dalam suasana seperti ini, siswa akan merasa aman untuk mengingat dan menggunakan pelajaran/pengetahuan sebelumnya, serta dapat 
mengembangkan dan mengemukakan pemikiran atau ide-idenya (De Porter, 2000).

Diskusi di antara siswa merupakan kegiatan yang ada pada fase kedua dalam PBM. Pada kegiatan ini bagi siswa maupun guru memerlukan kemampuan mengenali emosi siswa lain dan kemampuan membina hubungan dengan baik dan efektif dengan siswa lain. Menurut Sunandar (2008, h. 718) hubungan baik sesama teman dengan bisa memahami kondisi dan keberadaan teman secara apa adanya menjadikan modal yang besar untuk berkolaborasi dalam penyelesaian masalah matematis yang diberikan guru. Lebih lanjut Sunandar (2008, h. 718) menyatakan bahwa membina hubungan baik dan efektif dengan siapapun serta mengenali emosinya merupakan salah satu pintu kesuksesan belajar, karena kesulitan apapun yang dialami oleh seorang siswa bila hubungannya baik dengan semua orang, akan mudah mendapatkan jalan penyelesaian. Dalam hal ini guru memfasilitasi jalannya diskusi secara hati-hati sehingga tidak ada siswa yang merasa tertekan, dianggap bodoh, dan hal lain yang membuat siswa menjadi tidak empati pada siswa lain serta memperburuk hubungan antar siswa.

Pada akhir fase pembelajaran dalam PBM, siswa bekerja dalam komunitas belajar. Pada fase inilah banyak hal yang dapat dipelajari siswa maupun guru. Para siswa dapat bertukar ide atau pendapat dengan siswa lainnya dalam proses menyelesaikan masalah, sehingga memperoleh pemahaman baru tentang matematika yang disisipkan pada masalah tersebut. Selain itu, para siswa mencari hubungan, menganalisis pola, menemukan metode mana yang sesuai atau tidak sesuai, menguji hasil, menilai, mengkritisi pemikiran temannya, dan mengkreasi solusi dari masalah. Melalui aktivitas ini secara optimal mereka melibatkan diri dalam proses pembelajaran matematika. Perasaan nyaman untuk mengambil resiko, mengungkapkan ide, pendapat, dan alasan matematis, merupakan hal yang utama dalam fase ini. Namun demikian, dengan proses yang terus menerus seperti ini, kecerdasan emosional guru dan siswa dituntut terlibat secara intensif. Karena, tanpa kehadiran kecerdasan emosional guru maupun siswa, kegiatan atau situasi itu tidak secara lancar terbentuk bahkan mungkin akan menimbulkan stress berlebihan di dalam kelas. Sementara itu menurut Kato dan McEwen (Willis, 2010, h. 83) apabila stres terjadi di dalam kelas secara berlebihan akan menyebabkan gangguan pada memori jangka pendek dan jangka panjang serta menurunnya kualitas kinerja siswa.

Lebih jauh, pada fase akhir dalam PBM, guru mengkondisikan suasana siswa tidak merasa terlalu dinilai oleh orang lain. Memberi penilaian terhadap siswa dengan berlebihan dapat dirasakan sebagai ancaman sehingga menimbulkan kebutuhan akan pertahanan diri (Ali dan Asrori, 2008, h. 56). Walaupun 
kenyataannya, pemberian penilaian tidak dapat dihindarkan dalam situasi sekolah, tetapi paling tidak harus diupayakan agar penilaian tidak mencemaskan siswa, melainkan menjadi sarana yang dapat mengembangkan sikap kompetitif secara sehat. Dengan demikian, pada saat siswa mengungkapkan dan memikirkan secara individual dan secara bersama-sama ide-ide yang telah mereka kerjakan, guru harus berhati-hati dalam merespon (menilai) ide atau solusi yang disampaikan siswa.

Pada akhir diskusi dalam fase akhir PBM, dalam membuat ringkasan guru sebaiknya menggunakan istilah-istilah yang digunakan siswa kemudian secara hati-hati memperkenalkan istilah-istilah formal. Selain itu, hindari paksaan pada siswa untuk menggunakan suatu ide atau cara penyelesaian guna meyelesaikan permasalahan serupa di masa yang akan datang. Hal ini akan membuat siswa lebih nyaman dalam mengungkapkan ide atau cara penyelesaian di masa yang akan datang, sehingga keyakinan diri, keinginan melibatkan diri pada kegiatan berikutnya, keinginan untuk berhasil, akan bertambah baik (Goleman, 1996, h. 274).

Menurut Goleman, 1996; Sunandar, 2008, dan Shapiro, 2003 apabila unsurunsur yang berkaitan dengan kecerdasan emosional ini dilibatkan dengan baik selama proses pembelajaran maka membantu siswa dalam mempersiapkan menghadapi masalah belajar serta meningkatkan hasil belajar siswa. Dengan demikian, kehadiran kecerdasan emosional pada PBM diduga akan memacu sikap terbuka siswa dalam bertukar pikiran dan meningkatkan minat terhadap tantangan dari suatu masalah, serta diduga siswa tidak akan mudah putus asa dalam proses memecahakan masalah. Selain itu, pertimbangan-pertimbangan berkaitan dengan kecerdasan emosional yang diperhatikan dan diberi penekanan yang cukup pada proses pembelajaran, sesunggunya telah membina kecerdasan emosional atau bahkan mengembangkan kecerdasan emosional dari siswa itu sendiri (De Porter, 2000; Wilkinson, 2002; Shapiro, 2003; Goleman, 1996; Ali dan Asrori, 2008; Jensen, 2008).

Pada akhir bagian ini, yang perlu diperhatikan dan tidak terbantahkan bahwa guru merupakan faktor yang berpengaruh besar terhadap proses dan hasil pembelajaran siswa di kelas. Demikian juga pada pembelajaran matematika berbasis-masalah, guru dituntut memiliki kemampuan-kemampuan yang akomodatif. Hal ini untuk mendukung atau memandu kegiatan-kegiatan yang dilakukan siswa mulai dari fase pertama pembelajaran hingga fase akhir pembelajaran.

Keperluan untuk memiliki kecerdasan emosional yang tinggi dari seorang guru menjadi hal yang utama. Hal ini berdasarkan pada penelitian-penelitian para ahli kecerdasan emosional, yang menyatakan bahwa untuk 
mengembangkan atau melibatkan kecerdasan emosional dalam pola asuh anak harus diawali dari keteladan kecerdasan emosional yang baik dari orang tuanya (Syah, 1999, h. 138; Shapiro, 2003, h. 208, Darwis, 2006, h. 13).

\section{G. Penutup}

Dihadirkannya dimensi-dimensi dari kecerdasan emosional secara istimewa selama proses pembelajaran matematika berbasis-masalah dapat membantu siswa dalam mempersiapkan menghadapi masalah-masalah matematis yang diberikan. Kehadiran kecerdasan emosional pada pembelajaran matematika berbasis-masalah akan mendukung atau memandu kegiatan-kegiatan yang dilakukan siswa mulai dari fase pertama pembelajaran hingga fase akhir pembelajaran, sehingga diperolehnya hasil pembelajaran matematika secara utuh. Namun demikian, kecerdasan emosional yang tinggi dari seorang guru menjadi hal yang utama atau syarat perlu bagi berjalannya proses pembelajaran matematika berbasis-masalah yang menghadirkan kecerdasan emosional.

\section{H. Daftar Pustaka}

Ali, M. dan Asrori, M. (2008). Psikologi remaja. Jakarta: Bumi Aksara.

Crockcroft, W. H. (1981). Mathematics count: report into the teaching of mathematics in school under the chairmanship of W. H. Crockcroft. London, UK: HMSO.

Darwis, M. (2006). Model pembelajaran matematika dengan mempertimbangkan kecerdasan emosional. Disertasi pada PPS UNESA. Surabaya: Tidak diterbitkan.

De Porter, B. (2000). Quantum teaching. Bandung: Kaifa.

Dryden, G. dan Vos, J. (2000). The learning revolution (Revolusi cara belajar). Jakarta: PT. Kaifa.

Goleman, D. (1996). Emotional intelligence. Jakarta: Gramedia.

Goleman, D. (2000). Working with emotional intelligence. Jakarta: Gramedia.

Ibrahim (2011). Peningkatan kemampuan komunikasi, penalaran, dan pemecahan masalah matematis serta kecerdasan emosional melalui pembelajaran berbasismasalah pada siswa SMA. Disertasi pada SPs UPI. Bandung: Tidak diterbitkan.

Jensen, E. (2008). Brain-base learning. Yogyakarta: Pustaka Pelajar.

LeDoux, J. (2010). The emotional brain. Yogyakarta: Pustaka Baca.

Martin, D. A., (2003). Emotional quality management. Jakarta: Arga.

Martin, D. A., (2005). Smart emotion. Jakarta: Gramedia.

Mattes, C. T. W. (1979). Teaching and learning problem solving in science a general strategy. International Journal of Science Education, 57 (3), 882 - 885.

National Council of Teachers of Mathematics (2000). Principles and standarts for school mathematics. Reston, VA: NCTM.

Roh, K. H. (2003). Problem-based learning in mathematics. Clearinghouse for Science, Mathematics, and Environmental Education. [Online]. Available: http://www.vtaide.com/png/ERIC/PBL-in-Math.htm [7 September 2010]. 
Ruseffendi, E. T. (1988). Pengantar kepada membantu guru mengembangkan kompetensinya dalam pengajaran matematika untuk meningkatkan CBSA. Bandung: Tarsito.

Salovey, P. (2005). Emotional intelligence. Electonik Journal: [Online]. Available: http://kms.jpn.org/keynoteaddress6.pdf [31 Oktober 2009]

Santrock, W. J. (2007). Educational psychology. Texas: McGraw-Hill Company.

Savery, J. R. dan Duffy, T. M. (1995). Contructivist learning environments: case studies in instructional design. Dalam B.G. Wilson (ed). PBL: An instructional model and is constructivist framework. Englwood Cliffs, NJ: Educational Technology Publications.

Segal, J., (1997). Raising your emotional intellegence (Melejitkan kecerdasan emosional). Bandung: Kaifa.

Shapiro, E. L. (2003). Mengajarkan emotional intelligence pada anak. Jakarta: Gramedia.

Stien, J., Steven, B. E., Howard., (2000). The EI edge: emotional intellegence and your success (Ledakan EI). Bandung: Kaifa

Suharnan (2005). Psikologi kognitif. Surabaya: Srikandi.

Sumarmo, U. (2005). Pembelajaran matematika untuk mendukung pelaksanaan kurikulum tahun 2002 sekolah menengah. Makalah Disajikan pada Seminar Pendidikan Matematika di FPMIPA Universitas Negeri Gorontalo: Tidak diterbitkan.

Sunandar (2008). Pengaruh penilaian portofolio dan keceedasan emosional terhadap hasil belajar matematika topik dimensi tiga siswa kelas X SMA Negeri 4 Kendari tahun 2006. Dalam Rusgianto, dkk. (ed.). Prosiding seminar nasional nasional matematika dan pendidikan matematika. Yogyakarta: UNY.

Syah, M. (1999). Psikologi belajar. Jakarta: Logos.

Tan, O. S. (2004). Cognition, Metacognition, and problem based learning. Dalam O. S. Tan (ed.). Enhancing thinking through problem based learning approaches. Australia: Thomson.

Walle, V. A. J. (2005). Elementary and middle school mathematics. Singapore: Pearson Education.

Weissinger, A. P. (2004). Psycological tools in problem based learning. Dalam O. S. Tan (ed.). Enhancing thinking through problem based learning approaches. Australia: Thomson.

Willis, J. (2010). Strategi pembelajaran efektif berbasis riset otak. Yogyakarta: Mitra Media.

Wilkinson, P. D. (2002). Restructuring developmental math courses to enhance emotional intelligence. [Online]. Available: http://www.utne.com [7 September 2010].

Yusof, M. S. (2004). Peranan EQ dalam bidang pendidikan. Dalam Hamid (ed.). Panduan meningkatkan kecerdasan emosi. Kuala Lumpur: Profesional. 